\title{
Effect of Citrullus colocynthis L. (Cucurbitaceae) agglutinin on gene expression of caspases in Ectomyelois ceratoniae Zeller (Lepidoptera: Crambidae)
}

\author{
S. Ramzi, ${ }^{1}$ A. Sahragard, ${ }^{2}$ J.J. Sendi, ${ }^{2}$ A. Aalami ${ }^{3}$ \\ 1 Plant Protection Research Department, Horticultural Science Research Institute, Tea Research \\ Center, Agricultural Research Education and Extension Organization (AREEO), Lahijan; \\ ${ }^{2}$ Department of Plant Protection, Faculty of Agricultural Sciences, University of Guilan, Rasht; \\ ${ }^{3}$ Department of Agronomy and Plant Breeding, Faculty of Agricultural Sciences, University of \\ Guilan, Rasht, Iran
}

\begin{abstract}
The larvae of Ectomyelois ceratoniae Zeller were reared on the artificial diets containing $2 \%$ of Citrullus colocynthis L. (Cucurbitaceae) lectin and control to find any changes in gene expression of caspases. Specific primers were designed to amplify genes of six found caspases including Caspase 1, 2, 3, 4, 5 and 6. RNA of both treatments were extracted and cDNA molecules were synthesized prior to gene expression. Results of quantitative real-time polymerase chain reaction revealed that expression of all caspases in the fed larvae by $2 \%$ of lectin increased in comparison with control except for caspase 1 as 2.99, 5.7, $17.13,23.18,10.44$-fold. These results are consistent with our previous studies on the lower activities of digestive enzymes that are due to death of midgut cells followed by binding of lectin molecule.
\end{abstract}

\section{Introduction}

Apoptosis is a programmed cell death or suicide which play the critical roles in various physiological processes of insects such as immunity, development, reproduction, homeostasis, DNA damage, etc. (Courtiade et al., 2011). Cells engaged in the process have several characteristic marks such as membrane blebbing, chromatin condensation, disman-

Correspondence: Samar Ramzi, Department of Plant Protection, Tea Research Institute of Iran, Lahijan, 77555-44159, Iran.

E-mail: samar.ramzi@live.com ; sramzi@aero.ir

Key words: Ectomyelois ceratoniae; Citrullus colocynthis; lectin; life table.

Received for publication: 20 December 2015.

Revision received: 29 March 2016.

Accepted for publication: 29 March 2016.

(C) Copyright S. Ramzi et al., 2016

Licensee PAGEPress, Italy

Journal of Entomological and Acarological Research 2016; $48: 5699$

doi:10.4081/jear.2016.5699

This article is distributed under the terms of the Creative Commons Attribution Noncommercial License (by-nc 4.0) which permits any noncommercial use, distribution, and reproduction in any medium, provided the original author(s) and source are credited. tling of cellular contents, packaging of dead cell into apoptotic bodies prior to be phagocytized by immune-involved cells (Bryant, 2002). A group of cysteine-rich proteases called caspases are involved in apoptosis. Studies on ancestral origin of these enzymes revealed metacaspases in plants and fungi, paracaspases in slime molds and animals and true caspases in animals like insects (Koonin \& Aravind, 2002). Distribution of these enzymes is different within Animalia kingdom but all of them were synthesized as inactive form to prevent their damage to normal tissues (Courtiade et al., 2011). Five caspases have been reported in lepidoptera based on phylogenetic analyses through genomic, structural and functional studies (Courtiade et al., 2011). During apoptotic process, initiator caspases are activated initially leading to activate the effector caspases, which are responsible for cleavage of many cellular components as DNA fragmentation and membrane blebbing (Bryant, 2002).

Lectins are the carbohydrate-binding proteins in many organisms that bind reversibly to mono or oligosaccharides on the surface of cells (Peumans \& van Damme, 1995). Different studies have shown reduced performance of insects after adding lectins to their diets that may confirm lectins as the entomotoxic proteins. Histofluorescence studies revealed that lectins bind to epithelial cells of insect midgut and cause total loss of cell viability. In details, Hamshou et al. (2010) demonstrated that these molecules bind to specific carbohydrate moieties on the cell membrane proteins and start a signaling transduction cascade leading to death of the midgut epithelial cells.

Ectomyelois ceratoniae Zeller (Lepidoptera: Pyralidae) is a serious pest of pomegranate in Iran. Larvae utilize inner parts of fruit so control procedures have no suitable efficiencies against the pest. In our previous studies, we determined effects of a lectin from Citrullus colocynthis on life table, larval weight, survival, digestive physiology and intermediary metabolism of E. ceratoniae larvae (Ramzi \& Sahragard, 2013; Ramzi et al., 2014, 2015). Different concentrations of the lectin led to significant decrease of larval survival, weight, activity of digestive enzyme and intermediary metabolism. The current study was conducted to determine expression changes of caspase genes in the larvae of $E$. ceratoniae because lectins can harm epithelial cell of larval midgut because of their entomotoxic properties.

\section{Materials and methods}

Insect rearing

Larvae of $E$. ceratoniae were collected from pomegranate orchards 
and fed on artificial diet containing wheat bran (100 g), yeast $(3 \mathrm{~g})$, sugar $(10 \mathrm{~g})$, glycerine $(40 \mathrm{~mL})$ and water $(40 \mathrm{~mL})$ for at least 5 generations to have a homogeneous stock population at $28 \pm 2{ }^{\circ} \mathrm{C}, 85 \%$ of relative humidity and 16:8 h. L:D (Ramzi et al., 2014).

\section{Treatment of Ectomyelois ceratoniae larvae by Citrullus colocynthis lectin}

Artificial diets containing 0 (as control) and $2 \%$ of $C$. colocynthis agglutinin (CCA) were prepared and 30 newly laid eggs of $E$. ceratoniae were put on each diet. Hatched larvae were allowed to feed on control and CCA diets to the fifth larval instars.

\section{Larval dissection and RNA extraction}

Fifth larval instars of control and treated diets were dissected in diethylpyrocarbonate (DEPC) water and $50 \mathrm{mg}$ of their midguts were used for RNA extraction. Kit of Cynacolon Company (Cat \#RN7713C; Tehran, Iran) was used to extract RNA from larvae. Larval midguts (50 mg) were separately homogenized in $1 \mathrm{~mL}$ of $\mathrm{RNX}^{\mathrm{TM}}$ (plus) (CinnaGen Co., Teheran, Iran) solution and incubated for $5 \mathrm{~min}$ in room temperature prior to be vortexed. Then, $200 \mu \mathrm{L}$ of chloroform was added, shaked and incubated on ice for $5 \mathrm{~min}$. After $15 \mathrm{~min}$ of centrifugation, four phases were determined that the first one contained RNA that transferred to new tube. Equal volume of isopropanol alcohol was added to samples and those were centrifuged at 12,000 rpm for $15 \mathrm{~min}$. Then, $1 \mathrm{ml}$ of alcohol $75 \%$ was added and centrifugation was made at $7500 \mathrm{rpm}$ for $8 \mathrm{~min}$. Finally, samples were dried and $50 \mu \mathrm{L}$ of DEPC water was added abd quality of extracted RNA was evaluated in Agarose gel (1\%).

\section{Real-time polymerase chain reaction}

A kit from Thermo Fisher Scientific Co. (Waltham, MA, USA) was used to synthesize cDNA from control and treated larvae. Briefly, $5 \mu \mathrm{L}$ of RNA was incorporated by $0.5 \mu \mathrm{g}$ of Oligo dT and $11 \mu \mathrm{L}$ DEPC. The mixture was incubated at $60^{\circ} \mathrm{C}$ for $5 \mathrm{~min}$. After cooling, $4 \mu \mathrm{L}$ of reaction buffer, $2 \mu \mathrm{L}$ of deoxynucleotriphosphate $(10 \mu \mathrm{M})$ and $20 \mathrm{u}$ of
RNase inhibitor were added to $19 \mu \mathrm{L}$ of DEPC and incubated for 5 min at $37^{\circ} \mathrm{C}$. Then, $200 \mathrm{u}$ of Revert Aid M-Mulv was added and the reaction was incubated at $42^{\circ} \mathrm{C}$ for 60 min prior to final incubation at $70^{\circ} \mathrm{C}$ for $10 \mathrm{~min}$.

\section{Quantitative real-time polymerase chain reaction}

Reaction mixture contained $10 \mu \mathrm{L}$ of SYBR®Premix EXTaqTM (Takara Bio Inc., Shiga, Japan), $0.8 \mu \mathrm{L}$ of forward and reverse primers (Table 1), $0.4 \mu \mathrm{L}$ of dye and $2 \mu \mathrm{L}$ of cDNA. Amplification program was adopted as Table 1. Quantification of gene expression was calculated based on $2^{-\Delta \Delta \mathrm{Ct}}$ proposed by Schmittgen and Livak (2008). Data were normalized by using $18 S R R N A$ gene.

\section{Results and discussion}

Results of the current study revealed feeding of $E$. ceratoniae larvae on the diet containing $2 \%$ of $C$. colocynthis lectin affect expression of caspase genes. Figure 1 shows quality of the extracted RNAs from control and treated larvae indicating $28 \mathrm{~S}, 18 \mathrm{~S}$ and $5 \mathrm{~S}$ RNAs (Figure 1). The samples were used in polymerase chain reaction (PCR) of synthesized cDNA and results revealed specific amplification of caspase genes (Figure 2). Results of quantitative real-time-PCR revealed that expression of all caspases in treated larvae by $2 \%$ of lectin were increased in comparison with control except for caspase 1 as 2.99, 5.7, 17.13, 23.18, 10.44-fold (Table 2).

Suicide pathways of cells via apoptosis are the crucial phenomena in the life of living organisms. These paths are involved in the several physiological processes by the main roles of proteases with conserved domains called caspases (Accorsi et al., 2015). In lepidopterans, apoptosis is the main mechanism in metamorphosis on defence against pathogens (Courtiade et al., 2011). It has been reported 66 sequences out of 27 lepidopterous species with emphasis on presence of at least 5 caspases in insects although role of caspase 4 has not been yet eluci-

Table 1. Primers and polymerase chain reaction programs used in amplification of caspase genes.

\begin{tabular}{|c|c|c|}
\hline Primers & Amplification program & $\begin{array}{l}\text { Gene } \\
5 '-3 '\end{array}$ \\
\hline Caspase 1 & $\begin{array}{l}\text { Step 1: } 95^{\circ} \mathrm{C}, 2 \mathrm{~min} \\
\text { Step 2: } 95^{\circ} \mathrm{C}, 30 \mathrm{~s} \\
\text { Step 3: } 57.2^{\circ} \mathrm{C}, 30 \mathrm{~s} \\
\text { Step 4: } 72^{\circ} \mathrm{C}, 20.0 \mathrm{~s} \\
\text { Step 5: Repeat steps 2-4 } 29 \text { more times } \\
\text { Step 6: } 72^{\circ} \mathrm{C}, 5 \text { min } \\
\text { Step 7: } 4^{\circ} \mathrm{C} \text {, forever }\end{array}$ & $\begin{array}{l}\text { R: TGTCTAGCGCCCTTTATGCT } \\
\text { F: CATCTCCACCATTGGCTCTT }\end{array}$ \\
\hline Caspase 2 & - & $\begin{array}{l}\text { R: CAATCTGGGGTCTTTGAGGA } \\
\text { F: CACAGTCTTTTCCAGTGCCA }\end{array}$ \\
\hline Caspase 3 & - & $\begin{array}{l}\text { R: ACCTACGGAAAACCAAGCCT } \\
\text { F: CAGGTACTTTTTCCCCGACA }\end{array}$ \\
\hline Caspase 4 & - & $\begin{array}{l}\text { R: CGTTCCATTAACGAATCGGAG } \\
\text { F: AGCCTGTCTATTTCCTCGCA }\end{array}$ \\
\hline Caspase 5 & - & $\begin{array}{l}\text { R: ACATTCAATCCCATTCCCAA } \\
\text { F: TGAACTTGGTGCTCTTGACG }\end{array}$ \\
\hline Caspase 6 & - & $\begin{array}{l}\text { R: GACCGTGGTATGCCAAAAGT } \\
\text { F: TGCAGTGGCCCAATATATCA }\end{array}$ \\
\hline 18SrRNA & - & $\begin{array}{l}\text { F: CACGGGAAATCTCACCAGG } \\
\text { R: CAGACAAATCGCTCCACCAACTA }\end{array}$ \\
\hline
\end{tabular}


dated (Courtiade et al., 2011). In our study, caspase 5 showed the highest expression rate in comparison with other caspases except for caspase 1 with no expression. Shahidi-Noghabi et al. (2010) found that fed larvae of Choristoneura fumiferana Clemens (Lepidoptera: Tortricidae) on lectin I and II from Sambucus niger L. induced caspase 3 activity versus control. In details, SNA-I causes cell death via their wrinkling, condensing of nucleus and DNA fragmentation. Effect of the lectin was dose-dependent and killed the cells after four days. Similar results were observed followed by feeding on SNA-II. Hamshou et al. (2013) demonstrated that an agglutinin from Rhizoctonia solani de Bary bound to microvillar brush-border of the midgut in Spodoptera littoralis Hubner (Lepidoptera: Noctuidae) larvae, induced cell death, DNA fragmentation and increased activity of caspase 3. Also, Sprawka et al. (2013) showed that a phytohemagluttinin from fabaceae had a cytotoxic effect in the midgut of Sitobion avenae Fabricius (Hemiptera: Aphididae). The authors observed DNA fragmentation and increased activity of caspase 3 in the treated aphids.

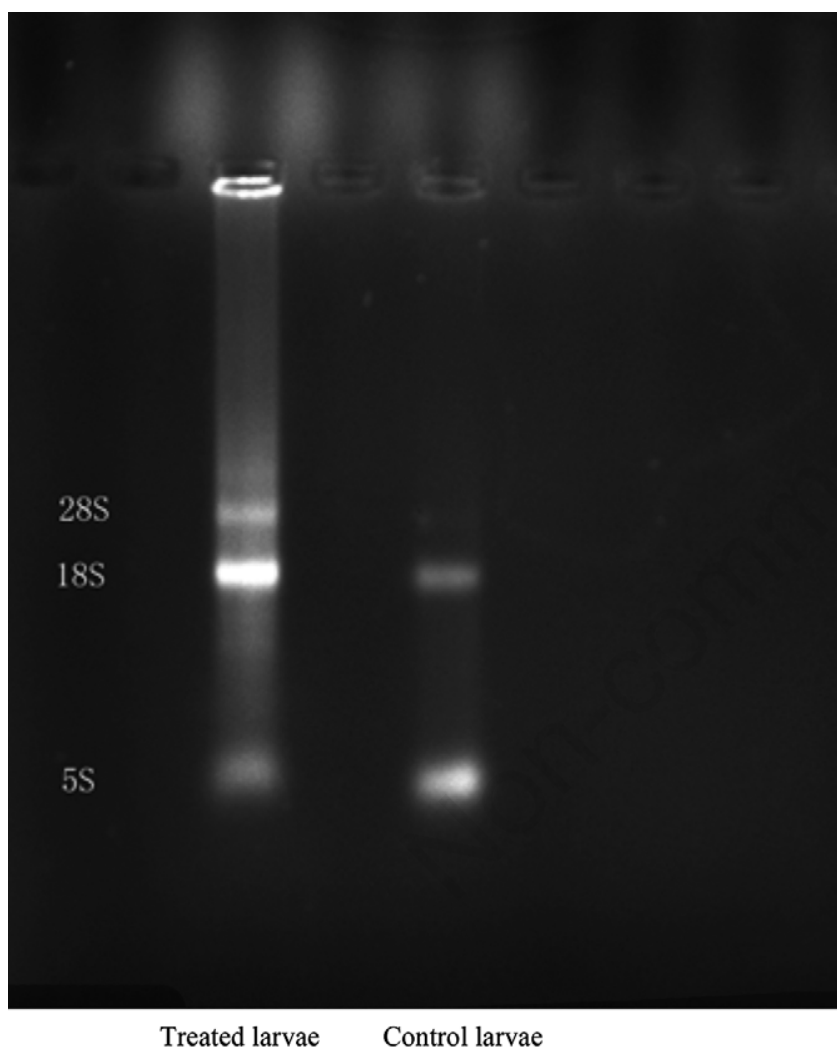

Figure 1. Quality of extracted RNA from control and treated larvae of Ectomyelois ceratoniae by Citrullus colocynthis lectin.

\section{Conclusions}

Caspases are the unique enzymes involved in programmed cell death caused during metamorphosis or defend against a xenobiotic factor. Since lectins bind to epithelial midgut cells of insects, programmed cell death by means of caspases remove dead cell and protect other cells. Our results showed as the first time increased expression of 5 out of 6 identified caspases in lepidopteran followed by feeding on CCA. Based on the earlier studies, if we consider main role of caspase 3 , it can be found expression rate of 5.7 -fold versus control. Also, our results highlighted previous studies on the cytotoxic effects of lectins on epithelial cells of insects and apoptosis via caspase activities. These results may be helpful to better elucidation of lectin entomotoxic mechanism followed by ingestion by an insect which may be helpful to find whether lectins cause similar results on non-target organisms or not.

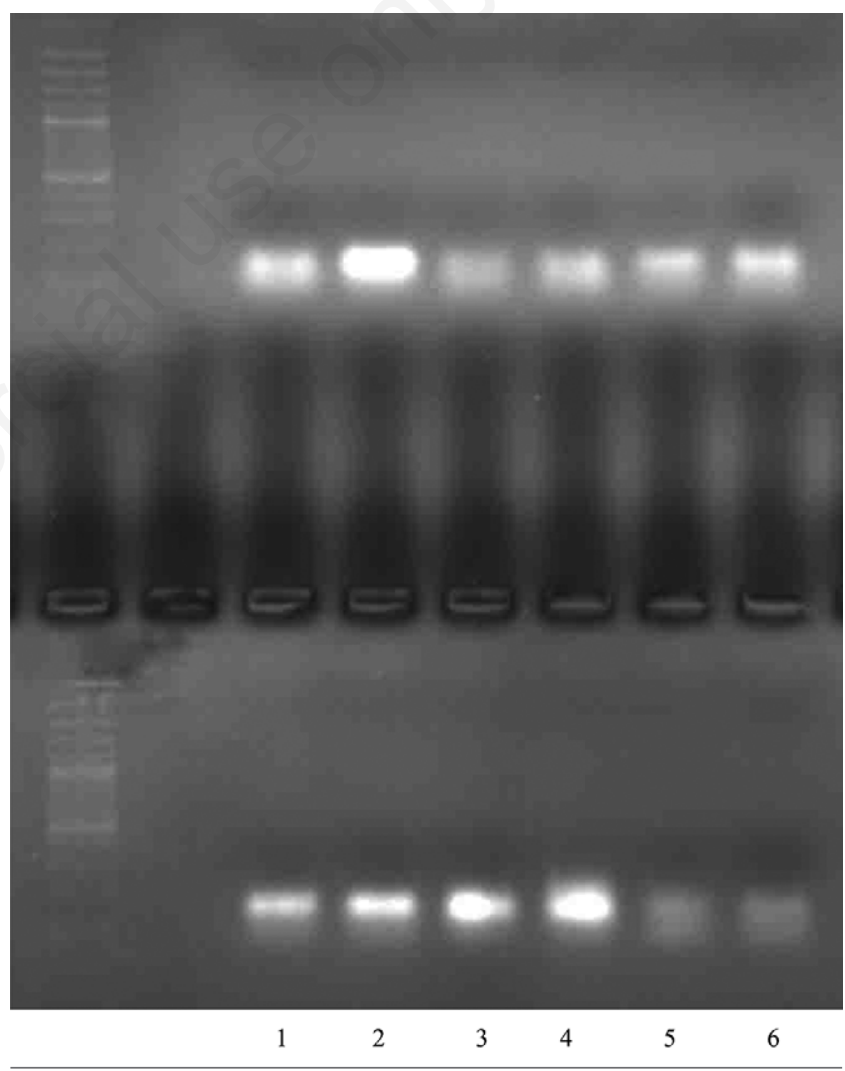

Figure 2. Amplification of caspase genes by specific primers. Top: treatment larvae; Down: control larvae.

Table 2. Gene expression of caspases in control and treated larvae of Ectomyelois ceratoniae fed on Citrullus colocynthis lectin.

\begin{tabular}{lcccccc} 
& Caspase 1 & Caspase 2 & Caspase 3 & Caspase 4 & Caspase 5 & Caspase 6 \\
Treatment & 15.12 & 18.48 & 23.16 & 17.45 & 12.21 & 10.28 \\
Control & 15.11 & 16.98 & 26.01 & 26.02 & 23.80 & 15.51 \\
\hline$\Delta \Delta$ Ct & 0.0066 & 1.49 & 2.85 & 8.56 & 11.59 & 5.22 \\
Expression ratio & 0.0013 & 2.99 & 5.7 & 17.13 & 23.18 & 10.44 \\
\hline
\end{tabular}




\section{References}

ACCORSI A., ZIBAEE A., MALAGOLI D., 2015 - The multifaceted activity of insect caspases. - J. Insect Physiol. 76: 17-23.

BRYANT W.B., 2002 - Caspases and caspase regulators in Lepidoptera and diptera. - Kansas State University. Dissertation: 144 pp.

COURTIADE J., PAUCHET Y., VOGEL H., HECKEL D.G., 2011 - A comprehensive characterization of the caspase gene family in insects from the order lepidoptera. - BMC Genom. 12: 357.

HAMSHOU M., SMAGGHE G., SHAHIDI-NOGHABI S., DE GEYTER E., LANNOO N., VAN DAMME E.J.M., 2010 - Insecticidal properties of Sclerotinia sclerotiorum agglutinin and its interaction with insect tissues and cells. - Insect. Biochem. Mole. Biol. 40: 883-890.

HAMSHOU M., VAN DAMME E.J.M., CACCIA S., CAPPELLE K., VAN DEN BORRE G., GHESQUIÈRE B., GEVAERT K., SMAGGHE G., 2013 High entomotoxicity and mechanism of the fungal GalNAc/Gal-specific Rhizoctonia solani lectin in pest insects". - J. Insect Physiol. 59: 295-305.

KOONIN E.V., ARAVIND L., 2002 - Origin and evolution of eukaryotic apoptosis: the bacterial connection. - Cell. Death. Differ. 9: 394-404.

PEUMANS W.J., VAN DAMME E.J.M. 1995 - The role of lectins in plant defense. - Histochem. J. 27: 253-271.

RAMZI S., SAHRAGARD A., 2013 - A lectin extracted from Citrullus colocynthis L. (Cucurbitaceae) inhibits digestive -amylase of Ectomyelois ceratoniae Zeller (Lepidoptera: Pyralidae). - J. Entomol. Acarol. Res. 45: 110-116.

RAMZI S., SAHRAGARD A., SENDI J.J., AALAMI A., 2014 - Effects of Citrullus colocynthis L.(Cucurbitaceae) lectin on survival, digestion and energy reserves of Ectomyelois ceratoniae Zeller (Lepidoptera: Pyralidae). Front. Physiol. - 4: 328.

RAMZI S., SAHRAGARD A., SENDI J.J., AALAMI A., 2015 - Effect of Citrullus colocynthis (Cucurbitaceae) agglutinin on the life table parameters of Apomyelois ceratoniae (Lepidoptera: Pyralidae). - J. Crop Prot. 5: 1931.

SCHMITTGEN T.D.M., LIVAK K.J., 2008 - Analyzing real-time PCR data by the comparative CT method. - Nat. Protoc. 3: 1101-1108.

SPRAWKA I., GOŁAWSKA S., PARZYCH T., GOŁAWSKI A., CZERNIEWICZ P., SYTYKIEWICZ H., 2013 - Induction of apoptosis in the grain aphid Sitobion avenae (Hemiptera: Aphididae) under the influence of phytohaemagglutinin PHA. - Appl. Entomol. Zool. 48: 525-532. 